\title{
Participação popular e endemias: uma nova conjuntura
}

Independentemente das obrigações que os governos federal, estaduais e municipais julguem ter com o pagamento das dívidas externa e interna ou com outros gastos vistos como prioritários, o combate às endemias é necessariamente uma tarefa governamental. A natureza de determinadas endemias, tais como as de malária ou de dengue, por exemplo, não pode ser enquadrada unicamente dentro de uma perspectiva espacial municipal. $O$ termo participação popular possui uma certa ambigüidade, a não ser que seja permanentemente contextualizado. Assim, o sentido do termo é essencialmente o de resposta, de cobrança da população organizada para que os governos cumpram seu papel. Na medida em que as autoridades não levam em conta essa cobrança, formas alternativas de participação popular se manifestam, e as combinações entre os governos, os mediadores (profissionais) e a população são múltiplas.

A permanência e até o crescimento de determinadas situações endêmicas na América Latina, à luz de uma conjuntura de globalização e de políticas neo-liberais, foram os elementos que serviram como incentivo para a produção deste número temático dos $\mathrm{Ca}$ dernos de Saúde Pública sobre Controle de Endemias e Participação Popular.

De certa forma, poder-se-ia dizer que um governo define sua preocupação com o combate às endemias quando estabelece suas prioridades de investimentos. A longa tradição dos governos brasileiros de solicitar a participação da população - e principalmente das classes populares - neste combate indica uma ação frágil e inadequada. É necessário um certo cuidado com as análises que se fazem da eficácia da resposta popular a esses convites, pois a iniciativa de ação teria que estar com os governantes. Pedir a colaboração das classes populares sem levar em conta o fato de que estas vivem geralmente em condições de vida inadequadas, de que pagam impostos altos e percebem rendimentos que estão entre os mais baixos no mundo, pode criar a impressão de uma resposta aquém do esperado. A baixa participação dos cidadãos brasileiros nas decisões de governos freqüentemente impositivos pode criar a ilusão de ótica de que a vontade de mudança de comportamento no combate às endemias é muito limitado, dessa forma deslocando a culpabilização para a população que é vítima da endemia.

Os convites dirigidos aos pesquisadores que participam deste número temático tiveram o intuito de incluir estudos que tanto representavam regiões geográficas, quanto endemias diversas. E, como o leitor verá, as posturas metodológicas, bem como as concepções de participação popular, representam atitudes diversas.

O que parece fundamental, no entanto, é que o grave quadro de endemias no Brasil não seja naturalizado. Independentemente das várias maneiras de se combater a dengue, através da participação popular, por exemplo, não se pode esquecer que o reaparecimento do mosquito Aedes aegypti no Brasil deu-se essencialmente por uma questão de vigilância sanitária deficiente. Todas as formas de participação popular no combate à dengue no Estado do Rio de Janeiro não podem ofuscar a negligência governamental nos anos de 19951997.

As classes populares desenvolvem uma participação popular como forma permanente e intrínseca de sobrevivência. Não é um convite dos governantes que determina essa participação. Assim, a participação ou não dessas classes no combate às endemias é essencialmente uma questão política. Por essas razões, não se deve permitir que os aspectos técnicos deste combate - sem negar sua importância - naturalizem as responsabilidades pela permanência, e até agudização, das endemias no Brasil.

\section{Victor Vincent Valla}

Departamento de Endemias Samuel Pessoa

Escola Nacional de Saúde Pública

Fundação Oswaldo Cruz 


\section{Community participation and endemic diseases: a new contest}

Even though the federal, state, and municipal governments in Brazil feel they must pay off the internal and external debts as well as other expenses that are considered priorities, programs to combat endemic diseases are necessarily governmental tasks. The nature of such endemic diseases as malaria and dengue cannot be limited exclusively to a municipal territorial perspective. The term popular participation remains ambiguous unless it is considered within a specific context. In this sense, the term's meaning is essentially one of response, of demands by popular organizations that governments fulfill their roles. To the extent that public authorities fail to take such demands into consideration, alternative forms of popular participation will arise, expressing various combinations of relationships between citizens' groups, health professionals, and government representatives.

The persistence and spread of endemic diseases within a context of globalization and neoliberal policies were factors that served as incentives for this thematic issue of Cadernos de Saúde Pública on The Control of Endemic Diseases and Popular Participation.

One could say that a government defines its concerns over endemic diseases when it establishes priorities for investing public monies. Brazilian governments have traditionally solicited participation by the population, especially from the popular or working classes, a tradition which suggests a weak, inadequate policy in combating endemic diseases. It is thus necessary to carefully analyze studies focusing on the efficacy of the popular response to such invitations, since the initiative should be a characteristic principally of the government authorities. To ask the working class to collaborate with no regard for its inadequate living conditions, high taxes, and depressed income (among the lowest in the world) creates the impression of an inadequate response to the invitation. The limited participation by Brazilian citizens in decisions by authoritarian administrations produces the optical illusion that the people refuse to change their habits to help combat endemic diseases. Responsibility for failing to combat endemic disease is thus shifted to the shoulders of that segment of the population that includes its main victims.

Participating authors in this thematic issue were invited to submit articles focusing on different endemic diseases in various parts of Brazil and other Latin American countries. One notes that both the methodological approaches and concepts of popular participation are highly diversified.

It is essential that the serious situation of endemic diseases in Brazil not be taken for granted as something natural. Regardless of the various available forms of combating dengue through popular participation, one should not forget that the reemergence of the Aedes aegypti mosquito was a problem of health surveillance. The various possible forms of popular participation in the struggle against dengue in the State of Rio de Janeiro should not overshadow the government's negligence during the 1995-1997 period.

The working-class population practices popular participation as an intrinsic and permanent form of survival. Whether it chooses to participate in the struggle against endemic diseases is essentially a political issue. Therefore, although technical issues are crucial, they should not be allowed to overshadow the underlying responsibilities for the persistence and even aggravation of endemic diseases in Brazil.

Victor Vincent Valla

Departamento de Endemias Samuel Pessoa

Escola Nacional de Saúde Pública

Fundação Oswaldo Cruz 